\title{
School-Enterprise Cooperation Construct a New Educational Model of Mechanical Talent for Independent Colleges
}

\author{
Xiaomei $\mathrm{Li}^{1}$, Qiaolian $\mathrm{Du}^{2}$, Chengjun Huang ${ }^{3}$ \\ Zhejiang Normal University, Jinhua, Zhejiang, 321004 ,China,

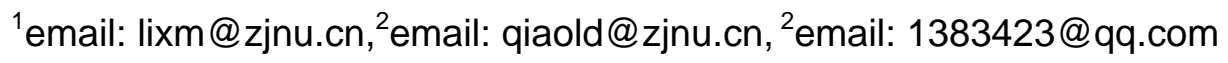

Keywords: school and enterprise cooperation; cooperation;training mode; excellent engineers; independent college

\begin{abstract}
Independent colleges has become an important part of higher education in our country, how to cultivate a distinctive mechanical professional Independent-college graduates is a common concern of issue.According to the characteristics of the independent-college, the premise of the personnel training mode is combined with the needs of economic construction and development to build practical talent training scheme.Under the guidance of the talent training scheme, through the interaction between school and enterprise, exploring a new teaching model of production, teaching and research integration for talents. Through practice of working with companies(such as Hongwuhuan Group),obtain an excellent effect.which explored a successful path for independent college.cultivating professional talents of machinery both own professional knowledge and engineering consciousness.
\end{abstract}

\section{Introduction}

Independent-college established by the cooperation with public college and social power, approved by the ministry of education,mainly carries on the education of undergraduate level higher education institutions.Due to the change of requirement of market economy and the fierce competition in the job market, how to broaden the employment channels for students, to use the social resources, to construction of independent-college personnel training mode, to establish suitable for their own development education model of "industry-university-institute" cooperation, have owns college characteristics, have own professional characteristic, for the local enterprises to cultivate good foundation, high quality, strong practical applied talents, is a problem worth our research and explore.

\section{Mechanical professional construction of personnel training scheme}

In view of the need of talent from machinery industry,the talent training scheme of grade 2010 was revised.On the principle of "Value foundation,enhance capacity,Broaden knowledge,strengthen practice”,Professi-onal training goal,with mechanical design manufacturing and automation of basic knowledge and application ability, can in the industrial production of the first line in machinery manufacturing in the field of product design and manufacturing, technology development, application study, operation management and sales management and other aspects of the work of Applied Engineering and technical personnel.Teaching mode is shown in table 1 and figure 1

\section{School and enterprise cooperation, exploring the talent training in the new teaching mode}

A School and enterprise cooperation to formulate the talent training scheme Training program of grade 2011 is design by the training feasibility and practicability,invite Hongwuhuan Group's Egineering and technical and University of peer experts review this scheme,take the pulse of the enterprise demand,analysis the experts' view carefully,through repeated argument formulate a unique talent training scheme. 


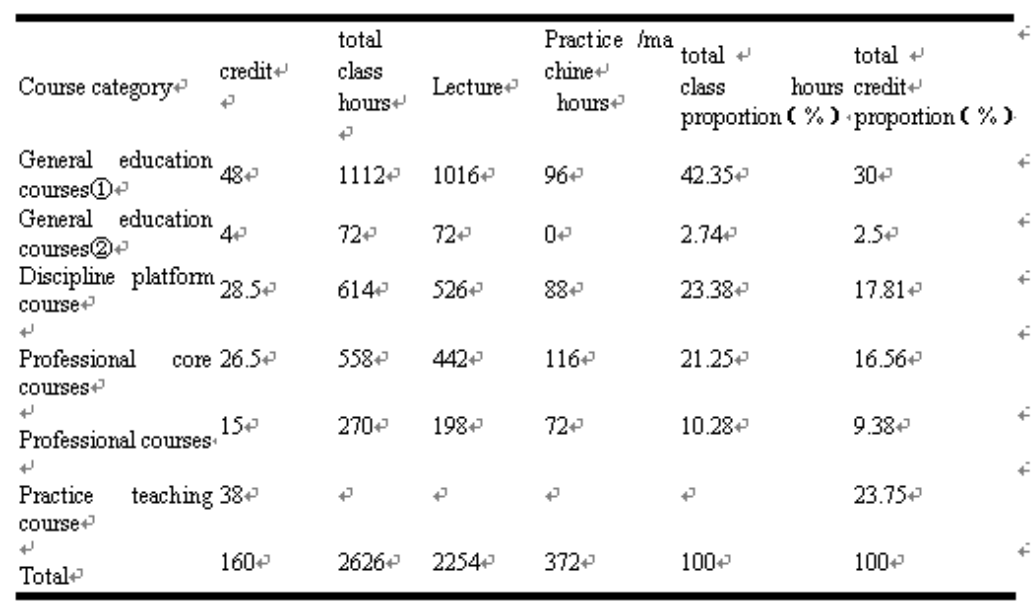

Table1 Credit and class hour assignment table B School and enterprise cooperation in professional education progress

Professional education is a key point.Broguht the grade 2010 freshmen to the enterprise,took them illuminative education as a part of professional education,in Hongwuhuan Group,fresmen listen to the introduction of general manager about their enterprise's development history, business strategy, product type and enterprise culture,Graduated from the Zhejiang University of the old engineers, graduated from Shanghai Jiao Tong University of the young engineers and German engineer introduced about mechanical fields successively.the grade 2008, 2009 and 2010 alumni of the enterprise take a face to face communication with the freshmen.Hongwuhuan Group's staff take the freshmen to visit the production line in workshop.Let the students know what is machinery manufacturing?How to be a good engineer?What role does the machinery manufacturing play in society?To help students clear professional orientation, and lay the foundation for future development.

C School and enterprise cooperation in laboratory construction

Heilongjiang Hongwuhuan Group and our college building construction machinery laboratory together.the enterprise to provide laboratory equipment, the school to provide venues and facilities,the establishment of this laboratory is special, so called specialty laboratory.Instrument and equipment in laboratory are provided by Hong group, including various series of air compressor, different kinds of air compressor parts and test device of air compressor,in addition by the enterprise provide teachers for case teaching. This way can make the students do the theory knowledge and the practice of zero distance connection.This lab used for teaching and experiment, mechanical professional graduation design, scientific research race,cultivating students' interests in and engineering consciousness and scientific research

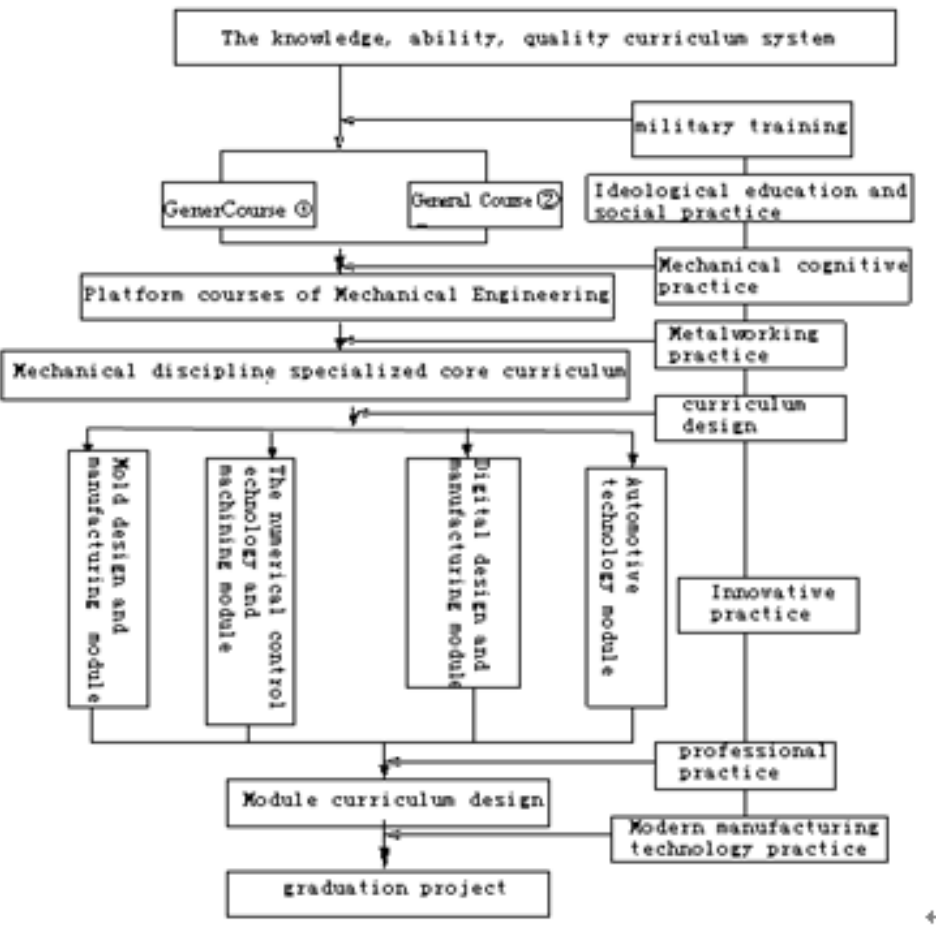
etc,in the premise of improving the

PICTURE 1 teaching quality and improving the students' professional skills,to seek more employment channels for students,to make graduates and employers more seamless.Cultivating talents through the school enterprise cooperation to build special lab,this teaching mode is open up a new path for Mechanical Engineering Major of Xingzhi College, Zhejiang Normal University.

D 4School and enterprise cooperation in practice teaching link 
Invite the enterprise engineer to do part-time teachers to guide practice teaching,In this semester mechanical grade 2008 opened "electromechanical transmission and control" course,invite Hongwuhuan Group's engineers enter the classroom to tech about Frequency conversion type air compressor's (LGV22A) control circuits and working principles. The instructional mode is vivid, the application of theoretical knowledge and engineering books on the engineering machine combined with organic, physical control, combining theory and application, for three-dimensional teaching.In the "hydraulic and pneumatic transmission" learning, The pneumatic pressure principle component diagram and working principle, from theory to practice, the physical dismantling, enable the students to master the structure characteristics at the same time, touch the equipment, operation it , have a more intuitive feel, enrich the experimental course.The teaching methods diversification.Not only invite the engineering technicians come to school,but also send the student to go to enterprises learn professional courses.Combined with the mechanical grade 2008 "mold design" course,Professional teachers lead students visited the Jinhua JG Tools Manufacturing Company and China Crown Group successively.The theoretical knowledge and application of the material will match, improve the students interest in learning expertise.Integrates theoretical teaching and practical teaching,take the practice teaching and theory teaching complement each other,build a distinctive pattern of practice teaching.

\section{E School and enterprise cooperation in graduation design teaching}

Through School-enterprise Cooperation to integrate graduation design teaching and practice, take the actual engineering as our graduation's design,it is a effective way to achieve the goal of cultivating talent machinery for Xingzhi College,besides,Graduates can get some working experience.Some of mechanical grade 2008 students who join in school enterprise cooperation program began to enter the link of graduation design,technicist come from enterprise as their tutors,their tutors will accord the enterprise in new product development design, manufacturing technology and technical innovation and so other actual content to select suitable topics. College arrange professional teacher assistant-coached,master requirements and progress, guarantee the quality of graduation design, complete the whole process of the graduation design.Interaction such a way that the student is the biggest beneficiaries of the school enterprise cooperation classmate, they will be better familiar with enterprise, help the enterprise to solve practical engineering problems, improve the ability to analyze and solve problems, in addition enterprises can get to know students' ablity will, make students can quickly adapt to the enterprise demand, and to improve enterprise competitiveness, at the same time also can improve the university teachers ability such as found that the problem, research questions and the ability to solve practical engineering problems, broaden the knowledge, rich experience, complete the function of institutions of higher learning..

\section{F School enterprise interaction about innovative practice}

In 2010 the national contest of three-dimensional digital division in Zhejiang Division, our college.Our school 2008 grade built two team to join this race,named imachine team and jianfeng team,material sources are in school enterprise cooperation enterprise products,one product is Hongwuhuan's drill rig,the other is ATV come from Buyang Group's Subsidiary Feishen vehicle,During the selected topic and research,enterprise gave strong support and help to them,Students used their knowledge learned from class, carried on the three-dimensional modeling and movement simulation for drill rig and ATV. in this process, they consolidate their knowledge, enrich their content, improve their ability, enhance the team spirit.Both of them won the special award of 3D digital contest Zhejiang Division.In 2010 the National Digital contest Hongwuhuan's drill rig won the national first award, champion ATV E110 won the the second award. 


\section{University-enterprise cooperation pattern of new development----draw a blueprint for school and enterprise cooperation to cultivate excellent engineers}

In recent years, the ministry of education launched excellence engineers engineering, put forward higher requirements on the higher education of engineering.Over the years, our college cooperation with enterprise has successfully hosted the 21 of university-enterprise class,the name of the school enterprise cooperation class is named by the enterprises' name,Mechanical grade 2008 attended four enterprise cooperation class,the four class is Hongwuhuan Class, Pioneer Class, Linixmotor Class, Radical Class,accounting for almost one-third of mechanical grade 2008 students. Grade 2010 students enrolled in the new round of the Hongwuhuan Class, a total of 32 people,Companies planning to take grade 2010 students from the school-enterprise cooperation into the school-school cooperation.Implementation "2+2"school.Only the first two years to study in our university, the second two years will go to study aerodynamics professional in xian Jiao Tong University because of the enterprise's investment.They will go back to work for the company after graduation , and implementation of Training Project Excellence Engineer.Enterprises according to their need to training ahead of time, make the school training students to seamlessly integrate with enterprise needs. Implement the project also need further elaboration.

\section{Complimentary Close}

Through the above in the talent cultivation in each teacing part,school close interaction with the enterprise,combined with the development of society demand ,this mode is popular among students and enterprises,It is not only the development of higher engineering education and one of important means to improve the quality of the engineering talents cultivation of independent college, but also a effective way to training excellent engineer.It was a long journey, in the process also needs to Advocate the new educational philosophy, Change the teachers and students' view of the traditional teaching,needs the joint efforts of the society and the school,can take on cultivation possess ability and knowledge, comprehensive quality good outstanding engineers historical mission.

\section{References}

[1] Pang Siqin. comparative with Mechanical professional courses and training mode between China and USA[J]. China University Teaching, ,2007（11） , 88-91

[2] Pearl River Delta area of reform and development planning framework(2010_2020)[N]. The People's Daily,2010-07-30013.

[3] Guo Zhongning etc. Mechanical engineering practice teaching link of the reform and exploration. Mechanical courses forum proceedings 2009，2009（10），257-260

[4] Li Peigen. The Chinese mechanical engineering academic tutorial[M]. Beijing: Tsinghua University Press, 2008

[5] Ministry of Education of the People's Republic of China, "Engineer training and Education Excellence program ” start session manual , [2010-06-23/2012-6-25] , [EB/OL]http: //www.gov.cn/gzdt/2010-06/23/content 1635114.html. 